CLINICAL STUDY

\title{
Isolated GH deficiency: mutation screening and copy number analysis of HMGA2 and CDK6 genes
}

\author{
Darya Gorbenko Del Blanco ${ }^{1,2}$, Laura C G de Graaff ${ }^{1,2}$, Dirk Posthouwer ${ }^{3}$, Theo J Visser ${ }^{4}$ and \\ Anita C S Hokken-Koelega ${ }^{1,2}$ \\ ${ }^{1}$ Pediatrics, Subdivision of Endocrinology, Erasmus University, Rotterdam, The Netherlands, ${ }^{2}$ Dutch Growth Research Foundation, Rotterdam, \\ The Netherlands, ${ }^{3}$ Internal Medicine, University Medical Center Utrecht, Utrecht, The Netherlands and ${ }^{4}$ Internal Medicine, Erasmus Medical Center, \\ Rotterdam, The Netherlands \\ (Correspondence should be addressed to D G del Blanco who is now at Erasmus MC, Internal Medicine, Room Number Ee502, Dr Molewaterplein 60, \\ 3015GJ Rotterdam, The Netherlands; Email: d.gorbenkodelblanco@erasmusmc.nl)
}

\begin{abstract}
Objective: In most patients, the genetic cause of isolated GH deficiency (IGHD) is unknown. By identifying several genes associated with height variability within the normal population, three separate genome-wide association studies provided new candidate genes for human growth disorders. We selected two of them for genetic screening of our IGHD population.

Aim: We aimed to determine whether high-mobility group A2 (HMGA2) and cyclin-dependent protein kinase 6 (CDK6) are involved in the pathogenicity of IGHD.

Methods: We directly sequenced coding regions and exon-intron boundaries of the genes HMGA2 and CDK6 in 105 Caucasian IGHD patients from the Dutch HYPOPIT study. In addition, we developed a new probe set of multiplex ligation-dependent probe amplification for both genes in order to detect copy number variations.

Results: In one patient with classical IGHD phenotype, we identified a new heterozygous 20 bp deletion in the intronic region of HMGA2 (c.250-29_-9del), which was absent in the databases and healthy controls. Together, with recently published data concerning the 12q14 microdeletion syndrome, where patients with an HMGA2 haploinsufficiency had proportionate short stature, this study provides further support of the important role for HMGA2 in growth. In CDK6, we found only known polymorphisms.

Conclusions: This study provides the first report of a deletion in the HMGA2 gene that might be related to IGHD. We suggest that this gene is investigated as a second screening in patients with a classical IGHD phenotype in which mutations in classical candidate genes have been excluded.
\end{abstract}

European Journal of Endocrinology 165 537-544

\section{Introduction}

Isolated GH deficiency (IGHD) is a congenital disorder characterized by growth failure due to low levels of $\mathrm{GH}$, not associated with other pituitary hormone deficiencies. Its most important clinical characteristics are proportionate short stature accompanied by retarded growth and delayed bone maturation, but mostly normal length and weight at birth. Other frequent findings include truncal obesity, a high-pitched voice, and delayed puberty, but normal fertility (reviewed (1)). The patients usually respond well to exogenous $\mathrm{GH}(2)$.

The reported prevalence of IGHD ranges from 1 in 3480 to 1 in 10000 live births (3). Five to thirty percent of cases have first-degree relatives with short stature (4), suggesting a genetic etiology. Even though mutations in GH1 and GHRHR have been found as a genetic cause of IGHD (reviewed (1)), the vast majority of patients do not carry mutations in these two genes.
This suggests that other genes are involved and the identification of these genes is important to elucidate the pathogenesis of this complex condition.

In recent years, genome-wide association (GWA) studies have revealed genes and biological pathways that were not previously known to be involved in human growth. In 2007, the first GWA study by Weedon et al. (5) identified high-mobility group A2 (HMGA2) as a new gene associated with childhood and adult height in the general population. Then, in 2008, three separate studies together reported 44 SNPs that were associated with height variability within the normal population (6-8). Only four of these loci were identified in all three studies, namely HMGA2, cyclin-dependent protein kinase 6 (CDK6), HHIP, and ZBTB38 (Fig. 1), and they have been confirmed as truly associated in meta-analyses $(9,10)$. Based on the published data, we focused our research on the first two of these genes. 


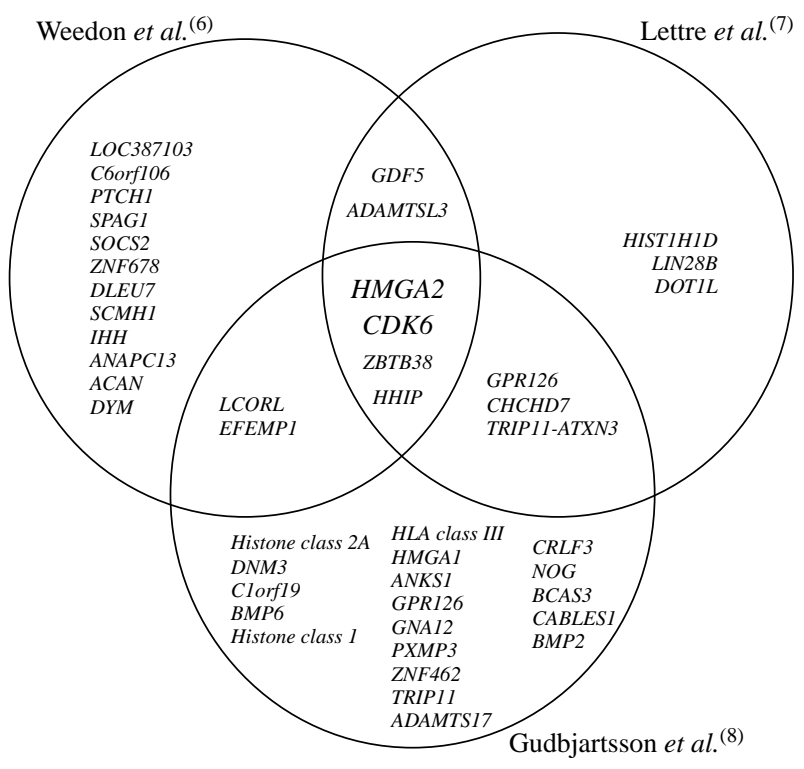

Figure 1 Overview of the loci associated with human height as revealed by recent GWA studies.

The high-mobility group A2 protein HMGA2 (MIM 600698 ) is an architectural transcription factor that is involved in several biological processes, including regulation of gene expression and embryogenesis. HMGA2 has several isoforms; HMGA2a is the major isoform, with proven transcription factor function. The other five splice variants $(b-f)$ have been identified by Hauke et al. and they lack exons 4 and 5. The expression of these isoforms has been detected in several normal and tumor tissues and also in cultured cells $(11,12)$; however, the function of these isoforms is currently unknown. HMGA2 is a transcription factor, and one target gene has been described and characterized: insulin-like growth factor 2 mRNA-binding protein (IGF2BP2, MIM ID 608289; previously known as IMP2) $(13,14)$. IGF2BP2 is an mRNA-binding protein that is involved in the post-transcriptional regulation of IGF2 (15), a major fetal growth factor. Two animal models show the role of HMGA2 in growth: homozygous knockout mice have a classical pygmy phenotype (16), and transgenic mice overexpressing a truncated HMGA2 protein have a giant and obese phenotype (17). In patients with the 12q14 microdeletion syndrome in whom the deletion affects HMGA2, one of the common characteristics is proportionate short stature (18-22). In 2005, Ligon et al. (23) described a case of pericentric inversion of chromosome 12 with intragenic rearrangement of HMGA2 in a boy with extreme somatic overgrowth.

The other gene we investigated, CDK6 (MIM 603368), is a member of the CDK family; CDKs form complexes with cyclins and regulate cell-cycle progression. CDK6 and its counterpart CDK4 bind to their corresponding (D-type) cyclins and regulate the progression through the $\mathrm{G} 1$ phase in cells that continue proliferating (24). Cdk4-null mice combine dwarfism phenotypes with infertility and resistance to human GHRH (25). Since it has been suggested that CDK6 compensates for loss of CDK4 and vice versa (26), mutations in CDK6 might also affect growth.

Based on the results of GWA studies and these other published data, we selected the candidate genes HMGA2 and CDK6 for mutation screening and copy number variation analysis in 105 Dutch patients with IGHD.

\section{Subjects and methods}

\section{Study subjects}

DNA samples were collected from 105 patients with IGHD who had participated in the Dutch HYPOPIT study, which investigates the genetic causes of GH deficiency (27). These patients had been recruited from the Endocrinology Departments at six university and two non-university hospitals and had been registered in the Dutch National Registry of Growth Hormone Treatment between 1992 and 2003. IGHD was defined as a peak $\mathrm{GH}$ response $<20 \mathrm{mU} / \mathrm{l}$ to arginine or clonidine test, or $<30 \mathrm{mU} / \mathrm{l}$ combined with serum IGF $1<-2$ SDS and normal serum levels of other pituitary hormones. Exclusion criteria were as follows: GH deficiency of known cause, such as a brain tumor, brain surgery, brain radiation, and known syndromes. Written informed consent was obtained from all participating patients and their parents or legal guardian(s).

\section{Sequencing}

DNA was isolated from the whole blood collected in EDTA tubes using standard procedures.

In all patients, HMGA2 (NM_003483.4) and CDK6 (NM_001259.6) coding exons and exon-intron boundaries were PCR amplified using Qiagen reagents of 5 units/ $\mu$ l Taq DNA Polymerase, $10 \times$ PCR buffer, $5 \times$ Q-Solution, $10 \mathrm{mM}$ dNTPs, $25 \mathrm{mM} \mathrm{MgCl}_{2}$, and primers (sequences available on request). Mixtures were incubated at $94{ }^{\circ} \mathrm{C}$ for $3 \mathrm{~min}$, followed by 35 cycles of $94{ }^{\circ} \mathrm{C}$ for $30 \mathrm{~s}$ and $60{ }^{\circ} \mathrm{C}$ for $1 \mathrm{~min}$ and $72^{\circ} \mathrm{C}$ for $1 \mathrm{~min}$, followed by a final incubation at $72{ }^{\circ} \mathrm{C}$ for $10 \mathrm{~min}$. The electrophoretic separation, sizing, and quantification of PCR products were performed using LabChip GX (Caliper Life Sciences, Hopkinton, USA) microfluidics technology. The amplified products were purified using illustra GFX 96 PCR purification kit (GE Healthcare). Sequencing was performed using Big Dye Terminator reaction kit (Applied Biosystems). After purification with Dyex 96 kit (Qiagen), the products were analyzed on a 3100 Genetic Analyzer (Applied Biosystems).

For each new variant, the degree of conservation of the affected residue was examined (Vertebral Multiz Alignment \& Conservation from UCSC database) as an estimate of its potential pathogenicity. 


\section{TaqMan SNP genotyping}

The frequency of any newly identified variant was estimated in the normal population by screening 188 chromosomes of healthy Caucasian volunteers (with heights between -2 and +2 SDS) using Taqman genotyping assay.

TaqMan SNP Genotyping Assay was performed using an ABI PRISM 7900HT sequence detection system following the manufacturer's instructions (Applied Biosystems). Two assays were used: C_58995818_10 targeting the SNP rs35654944 and Custom TaqMan SNP Genotyping Assay targeting the SNP rs73115423.

\section{Multiplex ligation-dependent probe amplification}

Copy number analysis was carried out using multiplex ligation-dependent probe amplification (MLPA) combined synthetic probes and the P200 kit with control sequences (MRC Holland, Amsterdam, The Netherlands). We designed a home-made probe set in order to detect deletions or duplication in all coding exons in HMGA2 (NM_003483.4) and CDK6 (NM_001259.6), plus the 3'-UTR region of HMGA2 known to be regulated by miRNAs. The homemade probe set contained products ranging from 98 to $166 \mathrm{bp}$ in size with a minimum product size difference of $4 \mathrm{bp}$, sufficient to be resolved by capillary electrophoresis (sequences available on request). The assay was performed according to the manufacturer's instructions and analyzed using Gene Marker software (SoftGenetics LLC, State College, PA, USA).

\section{Functional analysis of the HMGA2 mutant}

After informed consent, a skin biopsy was taken from the patient with the HMGA2 mutation and primary fibroblast cultures were established as described previously (28). The fibroblasts were maintained in DMEM/F12 medium (Invitrogen) supplemented with 9\% heat-inactivated fetal bovine serum (Invitrogen) and $1 \%$ penicillin/streptomycin (Invitrogen).

Total RNA from primary fibroblast cells grown in a $75 \mathrm{~cm}^{2}$ flask was extracted with High-Pure RNA Isolation kit (Roche). cDNA from $1 \mu \mathrm{g}$ total RNA was synthesized using TaqMan RT reagent (Roche).

SYBR Green I (Eurogentec, Liége, Belgium) was used as the detector dye for quantitative PCR. IGF2BP2 expression analysis was performed as described previously (14). Sense primers used for different HMGA2 splice variant expressions described by Cleynen et al. (14) were combined with different antisense primers as described by Hauke et al. $(11,12)$. Melting curves of the PCR products were performed for quality control. Relative expression was calculated using the cyclophilin A housekeeping gene (Applied Biosystem). Fold changes was calculated using this comparative $C_{\mathrm{T}}$ method.

\section{Statistical analysis}

All results are the mean of at least triplicate determinations from representative experiments. Values are expressed as mean \pm s.E.M.

\section{Results}

We screened the DNA of 69 patients with classical IGHD and 36 patients with partial IGHD, for mutations, deletions, and duplications. The clinical characteristics of the patients are shown in Table 1.

\section{Mutation screening}

We directly sequenced the complete coding region and intron-exon boundaries of HMGA2 and CDK6 in all 105 patients. In one patient, we identified a yet unknown heterozygous deletion in HMGA2. This was confirmed by the subcloning of the PCR product from the affected patient and the detection of two different fragments, the smaller fragment containing a $20 \mathrm{bp}$ deletion 9 bp before the start of exon 4 (c.250-29_-9del) (Fig. 2A). The deletion was detectable by electrophoresis of the PCR product from the patient's genomic DNA, showing a characteristic pattern of four bands (Fig. 2B). Taking advantage of this fact, we analyzed the PCR product of exon 4 in 94 healthy Dutch controls. The presence of only one wild-type band indicated that this

Table 1 Clinical data of 105 patients with IGHD. Data are expressed as median (interquartile range (IQR)) unless indicated otherwise.

\begin{tabular}{|c|c|c|}
\hline & IGHD $(n=69)$ & pIGHD $(n=36)$ \\
\hline Gender (M/F) & $47 / 22$ & $25 / 11$ \\
\hline Age (year) & 20 (16 to 24$)$ & 21 (16 to 24$)$ \\
\hline BW SDS & $-0.3(-0.9$ to 0.3$)$ & $-0.4(-0.9$ to 0.4$)$ \\
\hline BL SDS & $-0.6(-1.7$ to 0.2$)$ & $-1.4(-2.2$ to -0.4$)$ \\
\hline Gestational age (w) & 40 (38 to 40$)$ & 40 (38 to 40$)$ \\
\hline $\begin{array}{l}\text { HSDS at start of } \\
\text { GH treatment }\end{array}$ & $-3.4(-3.9$ to -2.6$)$ & $-3.0(-3.5$ to -2.5$)$ \\
\hline $\begin{array}{l}\mathrm{GH} \text { peak during } \\
\text { arginine test }(\mathrm{mU} / \mathrm{l})\end{array}$ & $\begin{array}{l}6(4 \text { to } 10) \\
\text { (normal >20) }\end{array}$ & $\begin{array}{l}16(9 \text { to } 19) \\
\text { (normal }>20)\end{array}$ \\
\hline $\begin{array}{l}\mathrm{GH} \text { peak during } \\
\text { clonidine test }(\mathrm{mU} / \mathrm{l})\end{array}$ & $\begin{array}{l}8(4 \text { to } 12) \\
\text { (normal >20) }\end{array}$ & $\begin{array}{l}16(11 \text { to } 18) \\
\text { (normal }>20)\end{array}$ \\
\hline IGF1 SDS & $-3.4(-4.8$ to -1.8$)$ & $-2.5(-3.7$ to -1.5$)$ \\
\hline IGFBP-3 SDS & $-5.0(-8.1$ to -3.6$)$ & $-5.9(-9.5$ to -1.0$)$ \\
\hline MRI abnormalities & $\begin{array}{l}22 \text { pts: normal } \\
35 \text { pts: abnormal } \\
(4 \text { triad })^{a}\end{array}$ & $\begin{array}{l}13 \text { pts: normal } \\
15 \text { pts: abnormal } \\
(1 \text { triad })^{a}\end{array}$ \\
\hline FDR with GHD & $15 \%$ & $3 \%$ \\
\hline Micropenis & $13 \%$ & $6 \%$ \\
\hline Neonatal jaundice ${ }^{b}$ & $20 \%$ & $22 \%$ \\
\hline Hypoglycemia & $12 \%$ & $6 \%$ \\
\hline
\end{tabular}

pIGHD, partial IGHD; BW, birth weight; BL, birth length; FDR, first-degree relatives; HSDS, height SDS.

${ }^{\text {a Triad }}=$ hypoplastic anterior pituitary, ectopic posterior pituitary and interrupted/invisible stalk.

${ }^{b}$ Prolonged neonatal jaundice: more than 3 weeks. 
A
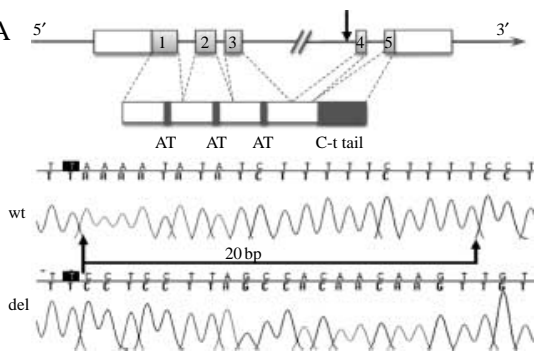

B

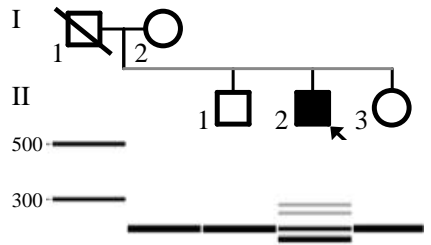

$100-$
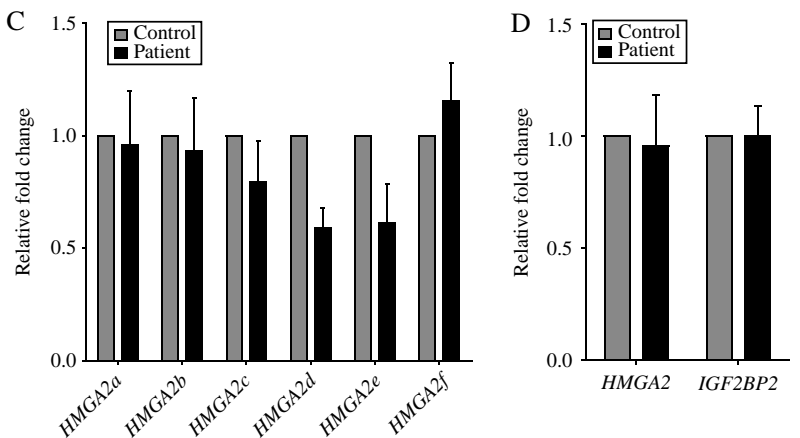

Figure 2 Deletion c.250-29_-9del in HMGA2. (A) Human HMGA2 gene and protein structure (adapted from Fusco \& Fedele (36); the vertical black arrow indicates the location of the deletion). Representative chromatograms of the wild-type sequence and the one carrying the deletion (arrows indicate the breakpoints). (B) Pedigree of the patient with the results of the PCR analysis of $H M G A 2$ exon 4 (the black arrow indicates index case).

(C) Quantitative gene expression analysis of HMGA2 splice variants in RNA from patient and control fibroblasts (mean \pm S.E.M.). (D) Quantitative gene expression analysis of HMGA2 and IGF2BP2 in RNA from patient and control fibroblasts (mean \pm S.E.M.).

deletion was absent in normal controls. The same analysis of genomic DNA from the phenotypically normal mother and two siblings of the patient also showed only the single wild-type band (Fig. 2B). Genetic material from the father with normal height of $185 \mathrm{~cm}$ was not available.

Additionally, we identified several known and unknown variants in $H M G A 2$, all outside the coding regions (Table 2). In five patients, we identified the known heterozygous intronic variant rs73115423. The in silico approach predicted a possible effect on the donor splice site of exon 3. In order to determine its nature as a mutation (frequency $<1 \%$ ) or a polymorphism (frequency $>1 \%$ ), we determined its prevalence using TaqMan SNP Genotyping Assay in 94 healthy Dutch controls. The fact that the variant was present in $2.7 \%$ of the healthy Dutch controls confirms that it is probably a non-pathogenic polymorphism rather than a functional mutation causing IGHD. We also found three minor genetic variations outside the coding regions of HMGA2. Their functional impact is probably small, based on their location.

In CDK6, we found several known polymorphisms (Table 2). However, we did not find any new variants.

\section{Copy number analysis}

In addition to mutation screening, we used MLPA for HMGA 2 and CDK6 to screen DNA samples of all 105 (classical and partial) IGHD patients for deletions and duplications. In 101 patients, we did not detect any copy number variation; in four samples, the quality of DNA was not high enough for MLPA analysis, which is a very sensitive method. Because the probes were designed to cover the coding region, our MLPA kit did not cover the intronic $20 \mathrm{bp}$ deletion previously detected by sequencing.

\section{Clinical features of the patient with HMGA2 c.250-29_-9del deletion}

The patient is the son of non-consanguineous Dutch parents, born after 40 weeks of gestation with normal birth weight $(3400 \mathrm{~g})$ and length $(50 \mathrm{~cm})$. At the age of 3 years, however, his height SDS had decreased to -4.8. He had various phenotypic characteristics typical for IGHD, such as frontal bossing and a highpitched voice, as well as a doll's face and a micropenis. At the age of 3.5 years, his bone age was 1.3 years. He had an abnormal pituitary magnetic resonance imaging (MRI) with an undetectable anterior pituitary and an ectopic posterior pituitary, which was localized within the pituitary stalk (Fig. 3). The GH peak obtained during the arginine test was $3.0 \mathrm{mU} / \mathrm{l}$ (normal $>20 \mathrm{mU} / \mathrm{l}$ ). Serum IGF1 was $0.5 \mathrm{nmol} / \mathrm{l}(-6.0 \mathrm{SDS})$. All other pituitary hormones were normal. At the age of 3 years, GH treatment was started, to which the patient responded very well. His final adult height is $1.87 \mathrm{~m}$ (+0.6 SDS compared with the normal population).

\section{Functional studies}

We performed functional studies in order to assess whether the $20 \mathrm{bp}$ deletion in HMGA2 (c.250-29_$9 \mathrm{del}$ ) is pathogenic or not. For this purpose, we used the total RNA derived from the patient and control fibroblasts. In the first place, the presence of the $20 \mathrm{bp}$ deletion was confirmed in the genomic DNA derived from the fibroblasts and the size and sequence of the major full-length HMGA2 transcript (330 bp) were detected in both control and patient's samples (data not shown). Relative gene expression levels, determined 
Table 2 HMGA2 and CDK6 variants identified by sequencing in 105 patients.

\begin{tabular}{|c|c|c|c|c|c|c|}
\hline \multirow[b]{2}{*}{ Gene } & \multirow[b]{2}{*}{ Exon } & \multirow[b]{2}{*}{ Position/rs number } & \multirow[b]{2}{*}{ Alleles } & \multicolumn{3}{|c|}{ MAF } \\
\hline & & & & IGHD & Control & $\overline{\text { refSNPa }}$ \\
\hline \multirow[t]{7}{*}{ HMGA2 } & 1 & c. $111+63 C>G$ & $\mathbf{C} / \mathbf{G}$ & NA & & NA \\
\hline & & c. $111+85 G>C$ & $\mathrm{G} / \mathrm{C}$ & NA & & NA \\
\hline & 2 & - & & & & \\
\hline & 3 & rs73115423 & $\mathrm{T} / \mathbf{A}$ & $2.38 \%$ & $2.75 \%$ & $1.7 \%$ \\
\hline & & rs3834468 & $-/ \mathbf{G}$ & $8 \%$ & & NA \\
\hline & 4 & c. $250-29$-9del 20 & & $0.48 \%$ & $0 \%$ & NA \\
\hline & 5 & rs57800850 & $\mathrm{T} / \mathrm{C}$ & $0.48 \%$ & & NA \\
\hline \multirow[t]{8}{*}{ CDK6 } & 2 & - & & & & \\
\hline & 3 & rs35654944 & $\mathrm{C} / \mathrm{T}$ & $0.48 \%$ & $1.10 \%$ & NA \\
\hline & 4 & - & (p.Asp110Asn) & & & \\
\hline & 5 & rs2301557 & $\mathrm{C} / \mathrm{T}$ & $0.95 \%$ & & $2.7 \%$ \\
\hline & 6 & - & & & & \\
\hline & 7 & rs3731373 & $\mathrm{T} / \mathrm{C}$ & $5.7 \%$ & & $5.0 \%$ \\
\hline & & rs42043 & $\mathrm{G} / \mathrm{A}$ & $26.2 \%$ & & $28.3 \%$ \\
\hline & 8 & rs3731387 & TGTAT/- & $25.7 \%$ & & NA \\
\hline
\end{tabular}

MAF, minor allele frequency; NA, not available.

${ }^{a}$ MAF only shown if European population data were available at time of the study. The minor allele is indicated in bold.

from an average of triplicate real-time PCR experiments from fibroblast cDNA, did not show any changes in the expression of the major HMGA2 transcript (HMGA2a) in the patient compared with the control. Expression levels of five additional splice variants (HMGA2b-f) were measured; only the isoforms HMGA2d and HMGA2e showed a decreased expression in the patient compared with the control (Fig. 2C); the change in isoform (d) was statistically significant $(P=0.02)$. We also measured the expression of IGF $2 B P 2$, the only transcription target gene of HMGA2 known to date, and found similar levels for the control and the patient (Fig. 2D).

\section{Discussion}

We performed sequencing and copy number variation analysis in two new candidate genes, HMGA2 and CDK6, in 105 Dutch IGHD patients. Our main finding was the identification of a new $20 \mathrm{bp}$ intronic deletion (c.250-29_-9del) in HMGA2. This deletion was identified in one patient with classical IGHD and MRI abnormalities, from the cohort of 69 patients with classical IGHD, of whom 35 had MRI abnormalities. This deletion was absent in the mother and siblings of the patient, in the normal population screened in this study as well as in the 1000 Genomes database, where 629 individuals (release November 2010) have been sequenced.

HMGA2 is an architectural transcription factor with three DNA-binding domains (AT-hooks) and a C-terminal acidic tail (Fig. 2A). Exons 1-3 encode the three AT-hooks, exon 5 encodes the C-terminal tail. These two motifs are separated by a spacer encoded by exon 4 . The function of the C-terminal tail is not yet completely understood, but it could be involved in protein-protein interactions or transcription activity enhancement $(29,30)$. Hauke et al. $(11,12)$ have described the complex alternative splicing pattern of HMGA2, in which the five additional splice variants (b-f) differ from the major isoform (a) due to the replacement of exons 4 and 5 by sequences derived from the long intron 3 . The $20 \mathrm{bp}$ deletion that we found in our patient is localized $9 \mathrm{bp}$ before the start of exon 4, which could affect this complex alternative splicing pattern.

Studies on Hmga2-null mice with pygmy-phenotype provided the first target gene of HMGA2: IGF2BP2 (13, 14), a post-transcriptional regulator of IGF2. In order to evaluate the possible deleterious effect of the newly found $20 \mathrm{bp}$ deletion, we performed real-time RT-PCR of fibroblast RNA and analyzed the expression pattern

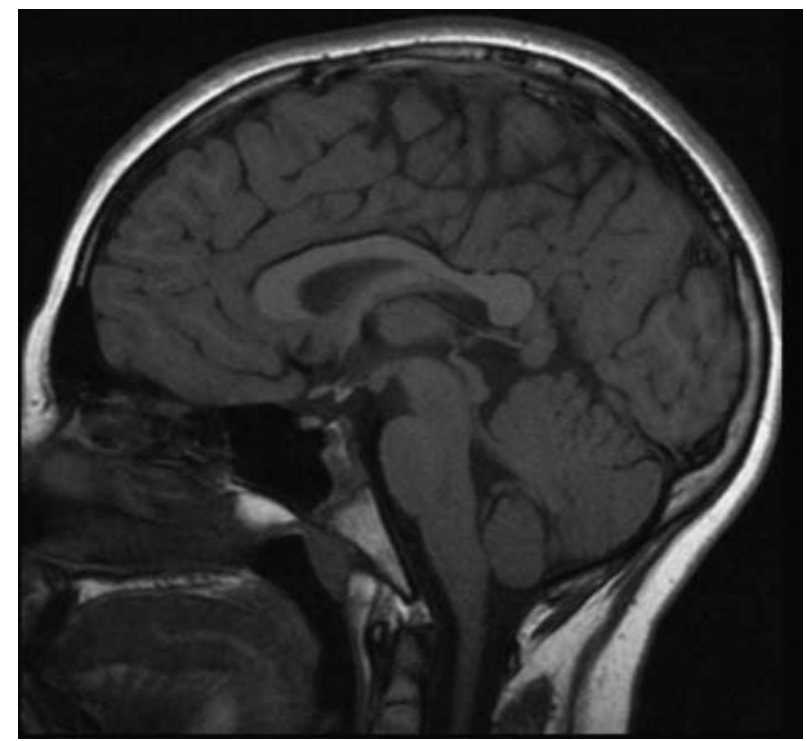

Figure 3 Pituitary structures on T1-weighted MRI scans of our patient with an undetectable anterior pituitary and an ectopic posterior pituitary. 
of the different HMGA2 splice variants as well as the IGF2BP2 gene, comparing the results between the affected patient and a normal control. Our initial hypothesis was that the expression of the major fulllength transcript (a) would be decreased, whereas expression of one or more of the other isoforms could be increased. However, in our experiments, the expression levels of the full-length transcript (a) were similar for the patient and control; this could be explained by the fact that the normal allele is still present in the patient. Surprisingly, two of the other five isoforms ( $\mathrm{d}$ and e) showed decreased expression (Fig. 2C). Currently, the function of these isoforms is unknown, but we cannot exclude the possibility that these low expression levels contribute to the patient's phenotype.

Although we expected to find decreased expression of HMGA2(a) and IGF2BP2, we did not find any changes during our experiments (Fig. 2D). One possible hypothesis for this is that the expression of these genes is only essential during embryogenesis (13) and could be less important in adult fibroblasts. It has been demonstrated that HMGA genes show high expression during human embryogenesis and fetal development and low expression levels in adult tissues (31, 32). In mice, Hmga 2 is found to be preferentially expressed by stem cells, showing a progressive decline in expression with age (33). Even though our patient was born with normal weight and height, the deficiency of an embryonic factor could cause an abnormal phenotype later in life. The deregulation and possibly decreased expression of HMGA2 during the development of specific somatotroph cells in the pituitary might lead to low GH production after birth, contributing to the IGHD phenotype.

Previous reports demonstrate the role of HMGA2 in human growth. Since 2007, several authors have described a new microdeletion syndrome affecting the $12 \mathrm{q} 14$ genomic region (18-22). A total of 13 patients with the $12 \mathrm{q} 14$ microdeletion syndrome have been described and the common features include low birth weight, failure to thrive in infancy, short stature, learning problems in childhood, and, in some cases, osteopoikilosis. The deletion covers several megabases and includes many genes, of which HMGA2 is thought to be responsible for the growth problems among the patients carrying this deletion. Later reports confirmed this role: patients carrying the deletion including HMGA2 all had severe growth retardation. In the last report of Lynch et al. (22), four children with the deletion ending before HMGA2 presented significantly better growth. Interestingly, Buysse et al. (19) identified an intragenic HMGA2 deletion in a boy with proportionate short stature without any other abnormalities and found that the deletion co-segregated perfectly with reduced adult height in the extended family of the boy. All these data provide evidence that a heterozygous deletion of HMGA2 causes growth failure. On the other hand, the report by Ligon et al. (23) describes a boy with extreme somatic overgrowth due to pericentric inversion of chromosome 12. Taken together, these data and the $20 \mathrm{bp}$ deletion described in the current study are consistent with an important role for HMGA2 in growth and suggest that copy number variations in this gene could be a rare genetic cause of IGHD or other disorders characterized by growth failure. In this regard, it is important to note the relevance of duplication and deletion screening in addition to sequencing, in order to achieve maximum genetic coverage and understanding of the disease $(34,35)$.

Contradictory to our expectation, we did not find any new pathological variants in CDK6. Although we did not examine the promoter and enhancer regions of either gene, we believe that it is reasonable to assume that CDK6 is not involved in the pathophysiology of IGHD and may be excluded in future screening of IGHD patients.

In conclusion, this study provides the first report of a deletion in the HMGA2 gene that might be a rare cause of IGHD. We suggest that this gene is investigated in patients with a classical IGHD phenotype, in whom mutations in the classical candidate genes GH1, GHRHR, have been previously excluded. At a molecular level, further research should be performed to better understand the possible involvement of this gene in the classical GH-IGF1 axis and to investigate how genetic alterations in HMGA2 can affect human growth.

\section{Declaration of interest}

The authors declare that there are no conflicts of interest that could be perceived as prejudicing the impartiality of the research reported.

\section{Funding}

This work was supported by the Dutch Growth Research Foundation.

\section{Acknowledgements}

We acknowledge Roel Brekelmans (MRC Holland) for help in developing the MLPA HMGA2 and CDK6-specific kit and Hannie Douben for technical help with the MLPA analysis. We acknowledge Dr Jose Carlos Moreno and Dr Edith Friesema for helpful discussions.

\section{References}

1 Alatzoglou KS \& Dattani MT. Genetic causes and treatment of isolated growth hormone deficiency - an update. Nature Reviews. Endocrinology 20106 562-576. (doi:10.1038/nrendo.2010.147)

2 Cohen P, Germak J, Rogol AD, Weng W, Kappelgaard AM \& Rosenfeld RG. Variable degree of growth hormone (GH) and insulin-like growth factor (IGF) sensitivity in children with idiopathic short stature compared with GH-deficient patients: evidence from an IGF-based dosing study of short children. Journal of Clinical Endocrinology and Metabolism 201095 20892098. (doi:10.1210/jc.2009-2139) 
3 Lindsay R, Feldkamp M, Harris D, Robertson J \& Rallison M. Utah Growth Study: growth standards and the prevalence of growth hormone deficiency. Journal of Pediatrics 1994125 29-35. (doi:10. 1016/S0022-3476(94)70117-2)

4 Phillips JA III \& Cogan JD. Genetic basis of endocrine disease. 6. Molecular basis of familial human growth hormone deficiency. Journal of Clinical Endocrinology and Metabolism $1994 \mathbf{7 8} 11-16$. (doi:10.1210/jc.78.1.11)

5 Weedon MN, Lettre G, Freathy RM, Lindgren CM, Voight BF, Perry JR, Elliott KS, Hackett R, Guiducci C, Shields B, Zeggini E, Lango H, Lyssenko V, Timpson NJ, Burtt NP, Rayner NW, Saxena R, Ardlie K, Tobias JH, Ness AR, Ring SM, Palmer CN, Morris AD, Peltonen L, Salomaa V, Davey Smith G, Groop LC, Hattersley AT, McCarthy MI, Hirschhorn JN \& Frayling TM. A common variant of HMGA2 is associated with adult and childhood height in the general population. Nature Genetics 200739 1245-1250. (doi:10. $1038 /$ ng2121)

6 Weedon MN, Lango H, Lindgren CM, Wallace C, Evans DM, Mangino M, Freathy RM, Perry JR, Stevens S, Hall AS, Samani NJ, Shields B, Prokopenko I, Farrall M, Dominiczak A, Johnson T, Bergmann S, Beckmann JS, Vollenweider P, Waterworth DM, Mooser V, Palmer CN, Morris AD, Ouwehand WH, Zhao JH, Li S, Loos RJ, Barroso I, Deloukas P, Sandhu MS, Wheeler E, Soranzo N Inouye M, Wareham NJ, Caulfield M, Munroe PB, Hattersley AT, McCarthy MI \& Frayling TM. Genome-wide association analysis identifies 20 loci that influence adult height. Nature Genetics 2008 40 575-583. (doi:10.1038/ng.121)

7 Lettre G, Jackson AU, Gieger C, Schumacher FR, Berndt SI, Sanna S, Eyheramendy S, Voight BF, Butler JL, Guiducci C, Illig T, Hackett R, Heid IM, Jacobs KB, Lyssenko V, Uda M, Boehnke M, Chanock SJ, Groop LC, Hu FB, Isomaa B, Kraft P, Peltonen L, Salomaa V, Schlessinger D, Hunter DJ, Hayes RB, Abecasis GR, Wichmann HE, Mohlke KL \& Hirschhorn JN. Identification of ten loci associated with height highlights new biological pathways in human growth. Nature Genetics 200840 584-591. (doi:10.1038/ ng.125)

8 Gudbjartsson DF, Walters GB, Thorleifsson G, Stefansson H, Halldorsson BV, Zusmanovich P, Sulem P, Thorlacius S, Gylfason A, Steinberg S, Helgadottir A, Ingason A, Steinthorsdottir V, Olafsdottir EJ, Olafsdottir GH, Jonsson T, Borch-Johnsen K, Hansen T, Andersen G, Jorgensen T, Pedersen O, Aben KK, Witjes JA, Swinkels DW, den Heijer M, Franke B, Verbeek AL, Becker DM, Yanek LR, Becker LC, Tryggvadottir L, Rafnar T, Gulcher J, Kiemeney LA, Kong A, Thorsteinsdottir U \& Stefansson K. Many sequence variants affecting diversity of adult human height. Nature Genetics 2008 40 609-615. (doi:10.1038/ng.122)

9 Lango Allen H, Estrada K, Lettre G, Berndt SI, Weedon MN, Rivadeneira F, Willer CJ, Jackson AU, Vedantam S, Raychaudhuri S, Ferreira T, Wood AR, Weyant RJ, Segre AV, Speliotes EK, Wheeler E, Soranzo N, Park JH, Yang J, Gudbjartsson D, Heard-Costa NL, Randall JC, Qi L, Vernon Smith A, Magi R, Pastinen T, Liang L, Heid IM, Luan J, Thorleifsson G, Winkler TW, Goddard ME, Sin Lo K, Palmer C, Workalemahu T, Aulchenko YS, Johansson A, Zillikens MC, Feitosa MF, Esko T, Johnson T, Ketkar S, Kraft P, Mangino M, Prokopenko I, Absher D, Albrecht E, Ernst F, Glazer NL, Hayward C, Hottenga JJ, Jacobs KB, Knowles JW, Kutalik Z, Monda KL, Polasek O, Preuss M, Rayner NW, Robertson NR, Steinthorsdottir V, Tyrer JP, Voight BF, Wiklund F, Xu J, Zhao JH, Nyholt DR, Pellikka N, Perola M, Perry JR, Surakka I, Tammesoo ML, Altmaier EL, Amin N, Aspelund T, Bhangale T, Boucher G, Chasman DI, Chen C, Coin L, Cooper MN, Dixon AL, Gibson Q, Grundberg E, Hao K, Juhani Junttila M, Kaplan LM, Kettunen J, Konig IR, Kwan T, Lawrence RW, Levinson DF, Lorentzon M, McKnight B, Morris AP, Muller M, Suh Ngwa J, Purcell S, Rafelt S, Salem RM, Salvi E, Sanna S, Shi J, Sovio U, Thompson JR, Turchin MC, Vandenput L, Verlaan DJ, Vitart V, White CC, Ziegler A, Almgren P, Balmforth AJ, Campbell H, Citterio L, De Grandi A, Dominiczak A, Duan J, Elliott P, Elosua R, Eriksson JG, Freimer NB, Geus EJ, Glorioso N, Haiqing S,
Hartikainen AL, Havulinna AS, Hicks AA, Hui J, Igl W, Illig T, Jula A, Kajantie E, Kilpelainen TO, Koiranen M, Kolcic I, Koskinen S, Kovacs P, Laitinen J, Liu J, Lokki ML, Marusic A, Maschio A, Meitinger T, Mulas A, Pare G, Parker AN, Peden JF, Petersmann A, Pichler I, Pietilainen KH, Pouta A, Ridderstrale M, Rotter JI, Sambrook JG, Sanders AR, Schmidt CO, Sinisalo J, Smit JH, Stringham HM, Bragi Walters G, Widen E, Wild SH, Willemsen G, Zagato L, Zgaga L, Zitting P, Alavere H, Farrall M, McArdle WL, Nelis M, Peters MJ, Ripatti S, van Meurs JB, Aben KK, Ardlie KG, Beckmann JS, Beilby JP, Bergman RN, Bergmann S, Collins FS, Cusi D, den Heijer M, Eiriksdottir G, Gejman PV, Hall AS, Hamsten A, Huikuri HV, Iribarren C, Kahonen M, Kaprio J, Kathiresan S, Kiemeney L, Kocher T, Launer LJ, Lehtimaki T, Melander O, Mosley TH Jr, Musk AW, Nieminen MS, O'Donnell CJ, Ohlsson C, Oostra B, Palmer LJ, Raitakari O, Ridker PM, Rioux JD, Rissanen A, Rivolta C, Schunkert H, Shuldiner AR, Siscovick DS, Stumvoll M, Tonjes A, Tuomilehto J, van Ommen GJ, Viikari J, Heath AC, Martin NG, Montgomery GW, Province MA, Kayser M, Arnold AM, Atwood LD, Boerwinkle E, Chanock SJ, Deloukas P, Gieger C, Gronberg H, Hall P, Hattersley AT, Hengstenberg C, Hoffman W, Lathrop GM, Salomaa V, Schreiber S, Uda M, Waterworth D, Wright AF, Assimes TL, Barroso I, Hofman A, Mohlke KL, Boomsma DI, Caulfield MJ, Cupples LA, Erdmann J, Fox CS, Gudnason V, Gyllensten U, Harris TB, Hayes RB, Jarvelin MR, Mooser V, Munroe PB, Ouwehand $\mathrm{WH}$, Penninx BW, Pramstaller PP, Quertermous T, Rudan I, Samani NJ, Spector TD, Volzke H, Watkins H, Wilson JF, Groop LC, Haritunians T, Hu FB, Kaplan RC, Metspalu A, North KE, Schlessinger D, Wareham NJ, Hunter DJ, O'Connell JR, Strachan DP, Wichmann HE, Borecki IB, van Duijn CM, Schadt EE, Thorsteinsdottir U, Peltonen L, Uitterlinden AG, Visscher PM, Chatterjee N, Loos RJ, Boehnke M, McCarthy MI, Ingelsson E, Lindgren CM, Abecasis GR, Stefansson K, Frayling TM \& Hirschhorn JN. Hundreds of variants clustered in genomic loci and biological pathways affect human height. Nature $2010 \mathbf{4 6 7}$ 832-838. (doi:10.1038/nature09410)

10 Lanktree MB, Guo Y, Murtaza M, Glessner JT, Bailey SD, OnlandMoret NC, Lettre G, Ongen H, Rajagopalan R, Johnson T, Shen H, Nelson CP, Klopp N, Baumert J, Padmanabhan S, Pankratz N, Pankow JS, Shah S, Taylor K, Barnard J, Peters BJ, Maloney CM, Lobmeyer MT, Stanton A, Zafarmand MH, Romaine SP, Mehta A, van Iperen EP, Gong Y, Price TS, Smith EN, Kim CE, Li YR, Asselbergs FW, Atwood LD, Bailey KM, Bhatt D, Bauer F, Behr ER, Bhangale T, Boer JM, Boehm BO, Bradfield JP, Brown M, Braund PS, Burton PR, Carty C, Chandrupatla HR, Chen W, Connell J, Dalgeorgou C, Boer A, Drenos F, Elbers CC, Fang JC, Fox CS, Frackelton EC, Fuchs B, Furlong CE, Gibson Q, Gieger C, Goel A, Grobbee DE, Hastie C, Howard PJ, Huang GH, Johnson WC, Li Q, Kleber ME, Klein BE, Klein R, Kooperberg C, Ky B, Lacroix A, Lanken P, Lathrop M, Li M, Marshall V, Melander O, Mentch FD, Meyer NJ, Monda KL, Montpetit A, Murugesan G, Nakayama K, Nondahl D, Onipinla A, Rafelt S, Newhouse SJ, Otieno FG, Patel SR, Putt ME, Rodriguez S, Safa RN, Sawyer DB, Schreiner PJ, Simpson C, Sivapalaratnam S, Srinivasan SR, Suver C, Swergold G, Sweitzer NK, Thomas KA, Thorand B, Timpson NJ, Tischfield S, Tobin M, Tomaszweski M, Verschuren WM, Wallace C, Winkelmann B, Zhang H, Zheng D, Zhang L, Zmuda JM, Clarke R, Balmforth AJ, Danesh J, Day IN, Schork NJ, de Bakker PI, Delles C, Duggan D, Hingorani AD, Hirschhorn JN, Hofker MH, Humphries SE, Kivimaki M, Lawlor DA, KottkeMarchant K, Mega JL, Mitchell BD, Morrow DA, Palmen J, Redline S, Shields DC, Shuldiner AR, Sleiman PM, Smith GD, Farrall M, Jamshidi Y, Christiani DC, Casas JP, Hall AS, Doevendans PA, Christie JD, Berenson GS, Murray SS, Illig T, Dorn GW II, Cappola TP, Boerwinkle E, Sever P, Rader DJ, Reilly MP, Caulfield M, Talmud PJ, Topol E, Engert JC, Wang K, Dominiczak A, Hamsten A, Curtis SP, Silverstein RL, Lange LA, Sabatine MS, Trip M, Saleheen D, Peden JF, Cruickshanks KJ, Marz W, O'Connell JR, Klungel OH, Wijmenga C, Maitland-van der Zee AH, Schadt EE, Johnson JA, Jarvik GP, Papanicolaou GJ, Grant SF, Munroe PB, North KE, Samani NJ, Koenig W, Gaunt TR, 
Anand SS, van der Schouw YT, Soranzo N, Fitzgerald GA, Reiner A, Hegele RA, Hakonarson H \& Keating BJ. Meta-analysis of dense genecentric association studies reveals common and uncommon variants associated with height. American Journal of Human Genetics 201188 6-18. (doi:10.1016/j.ajhg.2010. 11.007)

11 Hauke S, Flohr AM, Rogalla P \& Bullerdiek J. Sequencing of intron 3 of HMGA2 uncovers the existence of a novel exon. Genes, Chromosomes $\mathcal{E}$ Cancer $2002 \quad 34$ 17-23. (doi:10.1002/gcc. 10018)

12 Hauke S, Leopold S, Schlueter C, Flohr AM, Murua Escobar H, Rogalla P \& Bullerdiek J. Extensive expression studies revealed a complex alternative splicing pattern of the HMGA2 gene. Biochimica et Biophysica Acta 20051729 24-31. (doi:10.1016/j. bbaexp.2005.03.006)

13 Brants JR, Ayoubi TA, Chada K, Marchal K, Van de Ven WJ \& Petit MM. Differential regulation of the insulin-like growth factor II mRNA-binding protein genes by architectural transcription factor HMGA2. FEBS Letters $2004 \mathbf{5 6 9}$ 277-283. (doi:10.1016/j. febslet.2004.05.075)

14 Cleynen I, Brants JR, Peeters K, Deckers R, Debiec-Rychter M, Sciot R, Van de Ven WJ \& Petit MM. HMGA2 regulates transcription of the Imp2 gene via an intronic regulatory element in cooperation with nuclear factor-kappaB. Molecular Cancer Research 20075 363-372. (doi:10.1158/1541-7786.MCR-060331)

15 Nielsen J, Christiansen J, Lykke-Andersen J, Johnsen AH, Wewer UM \& Nielsen FC. A family of insulin-like growth factor II mRNA-binding proteins represses translation in late development. Molecular and Cellular Biology 199919 1262-1270.

16 Zhou X, Benson KF, Ashar HR \& Chada K. Mutation responsible for the mouse pygmy phenotype in the developmentally regulated factor HMGI-C. Nature $1995 \mathbf{3 7 6}$ 771-774. (doi:10.1038/ $376771 \mathrm{a} 0)$

17 Arlotta P, Tai AK, Manfioletti G, Clifford C, Jay G \& Ono SJ. Transgenic mice expressing a truncated form of the high mobility group I-C protein develop adiposity and an abnormally high prevalence of lipomas. Journal of Biological Chemistry $2000 \mathbf{2 7 5}$ 14394-14400. (doi:10.1074/jbc.M000564200)

18 Menten B, Buysse K, Zahir F, Hellemans J, Hamilton SJ, Costa T, Fagerstrom C, Anadiotis G, Kingsbury D, McGillivray BC, Marra MA, Friedman JM, Speleman F \& Mortier G. Osteopoikilosis, short stature and mental retardation as key features of a new microdeletion syndrome on 12q14. Journal of Medical Genetics 200744 264-268. (doi:10.1136/jmg.2006.047860)

19 Buysse K, Reardon W, Mehta L, Costa T, Fagerstrom C, Kingsbury DJ, Anadiotis G, McGillivray BC, Hellemans J, de Leeuw N, de Vries BB, Speleman F, Menten B \& Mortier G. The $12 \mathrm{q} 14$ microdeletion syndrome: additional patients and further evidence that HMGA2 is an important genetic determinant for human height. European Journal of Medical Genetics 200952 101-107. (doi:10.1016/j.ejmg.2009.03.001)

20 Mari F, Hermanns P, Giovannucci-Uzielli ML, Galluzzi F, Scott D, Lee B, Renieri A, Unger S, Zabel B \& Superti-Furga A. Refinement of the 12q14 microdeletion syndrome: primordial dwarfism and developmental delay with or without osteopoikilosis. European Journal of Human Genetics 200917 1141-1147. (doi:10.1038/ ejhg.2009.27)

21 Spengler S, Schonherr N, Binder G, Wollmann HA, Fricke-Otto S, Muhlenberg R, Denecke B, Baudis M \& Eggermann T. Submicroscopic chromosomal imbalances in idiopathic Silver-Russell syndrome (SRS): the SRS phenotype overlaps with the 12q14 microdeletion syndrome. Journal of Medical Genetics $2010 \mathbf{4 7}$ 356-360. (doi:10.1136/jmg.2009.070052)

22 Lynch SA, Foulds N, Thuresson AC, Collins AL, Anneren G, Hedberg BO, Delaney CA, Iremonger J, Murray CM, Crolla JA, Costigan C, Lam W, Fitzpatrick DR, Regan R, Ennis S \& Sharkey F. The 12q14 microdeletion syndrome: six new cases confirming the role of HMGA2 in growth. European Journal of Human Genetics 201119 534-539. (doi:10.1038/ejhg.2010.215)
23 Ligon AH, Moore SD, Parisi MA, Mealiffe ME, Harris DJ, Ferguson HL, Quade BJ \& Morton CC. Constitutional rearrangement of the architectural factor HMGA2: a novel human phenotype including overgrowth and lipomas. American Journal of Human Genetics 200576 340-348. (doi:10.1086/427565)

24 Malumbres M \& Barbacid M. Mammalian cyclin-dependent kinases. Trends in Biochemical Sciences 200530 630-641. (doi:10.1016/j.tibs.2005.09.005)

25 Jirawatnotai S, Aziyu A, Osmundson EC, Moons DS, Zou X, Kineman RD \& Kiyokawa H. Cdk4 is indispensable for postnatal proliferation of the anterior pituitary. Journal of Biological Chemistry 2004279 51100-51106. (doi:10.1074/jbc.M409080200)

26 Malumbres M, Sotillo R, Santamaria D, Galan J, Cerezo A, Ortega S, Dubus P \& Barbacid M. Mammalian cells cycle without the D-type cyclin-dependent kinases Cdk4 and Cdk6. Cell 2004 118 493-504. (doi:10.1016/j.cell.2004.08.002)

27 de Graaff LC, Argente J, Veenma DC, Herrebout MA, Friesema EC, Uitterlinden AG, Drent ML, Campos-Barros A \& HokkenKoelega AC. Genetic screening of a Dutch population with isolated GH deficiency (IGHD). Clinical Endocrinology 200970 742-750. (doi:10.1111/j.1365-2265.2008.03414.x)

28 Visser WE, Jansen J, Friesema EC, Kester MH, Mancilla E, Lundgren J, van der Knaap MS, Lunsing RJ, Brouwer OF \& Visser TJ. Novel pathogenic mechanism suggested by ex vivo analysis of MCT8 (SLC16A2) mutations. Human Mutation 2009 30 29-38. (doi:10.1002/humu.20808)

29 Yie J, Liang S, Merika M \& Thanos D. Intra- and intermolecular cooperative binding of high-mobility-group protein $\mathrm{I}(\mathrm{Y})$ to the beta-interferon promoter. Molecular and Cellular Biology 199717 3649-3662.

30 Noro B, Licheri B, Sgarra R, Rustighi A, Tessari MA, Chau KY, Ono SJ, Giancotti V \& Manfioletti G. Molecular dissection of the architectural transcription factor HMGA2. Biochemistry $2003 \mathbf{4 2}$ 4569-4577. (doi:10.1021/bi026605k)

31 Gattas GJ, Quade BJ, Nowak RA \& Morton CC. HMGIC expression in human adult and fetal tissues and in uterine leiomyomata. Genes, Chromosomes \& Cancer 199925 316-322. (doi:10.1002/ (SICI) 1098-2264(199908)25:4<316::AID-GCC2>3.0.CO;2-0)

32 Chiappetta G, Avantaggiato V, Visconti R, Fedele M, Battista S, Trapasso F, Merciai BM, Fidanza V, Giancotti V, Santoro M, Simeone A \& Fusco A. High level expression of the HMGI (Y) gene during embryonic development. Oncogene 199613 2439-2446.

33 Nishino J. Kim I, Chada K \& Morrison SJ. Hmga2 promotes neural stem cell self-renewal in young but not old mice by reducing p16Ink4a and p19Arf expression. Cell $2008 \quad 135$ 227-239. (doi:10.1016/j.cell.2008.09.017)

34 Kozlowski P, Roberts P, Dabora S, Franz D, Bissler J. Northrup H, Au KS, Lazarus R, Domanska-Pakiela D, Kotulska K, Jozwiak S \& Kwiatkowski DJ. Identification of 54 large deletions/duplications in TSC1 and TSC2 using MLPA, and genotype-phenotype correlations. Human Genetics 2007121 389-400. (doi:10. 1007/s00439-006-0308-9)

35 Dateki S, Fukami M, Uematsu A, Kaji M, Iso M, Ono M, Mizota M, Yokoya S, Motomura K, Kinoshita E, Moriuchi H \& Ogata T. Mutation and gene copy number analyses of six pituitary transcription factor genes in 71 patients with combined pituitary hormone deficiency: identification of a single patient with LHX4 deletion. Journal of Clinical Endocrinology and Metabolism 201095 4043-4047. (doi:10.1210/jc.2010-0150)

36 Fusco A \& Fedele M. Roles of HMGA proteins in cancer. Nature Reviews. Cancer 20077 899-910. (doi:10.1038/nrc2271)

Received 30 May 2011

Revised version received 27 July 2011

Accepted 29 July 2011 